\title{
The Complete Chloroplast Genome of Two Important Annual Clover Species, Trifolium alexandrinum and T. resupinatum: Genome Structure, Comparative Analyses and Phylogenetic Relationships with Relatives in Leguminosae
}

\author{
Yanli Xiong ${ }^{1,+}$, Yi Xiong ${ }^{1,+}{ }^{\circledR}$, Jun $\mathrm{He}^{2}$, Qingqing Yu ${ }^{1}{ }^{\mathbb{D}}$, Junming Zhao ${ }^{1}$, Xiong Lei ${ }^{1}$, \\ Zhixiao Dong ${ }^{1}$, Jian Yang ${ }^{1}$, Yan Peng ${ }^{1}$, Xinquan Zhang ${ }^{1, *}$ and Xiao Ma ${ }^{1, * \mathbb{C}}$ \\ 1 College of Animal science and Technology, Sichuan Agricultural University, Chengdu 611130, China; \\ yanlimaster@126.com (Y.X.); xiongyi95@126.com (Y.X.); yuqinggzu93@126.com (Q.Y.); \\ junmingzhao163@163.com (J.Z.); lxforage@126.com (X.L.); dongzhixiao94@126.com (Z.D.); \\ iwanwin@126.com (J.Y.); pengyanlee@163.com (Y.P.) \\ 2 State Key Laboratory of Exploration and Utilization of Crop Gene Resources in 10 Southwest China, \\ Key Laboratory of Biology and Genetic Improvement of Maize in 11 Southwest Region, Ministry of \\ Agriculture, Maize Research Institute of Sichuan 12 Agricultural University, Chengdu 600031, China; \\ hejunyer@outlook.com \\ * Correspondence: zhangxq@sicau.edu.cn (X.Z.); maroar@126.com (X.M.); Tel.: +86-28-86291010 (X.Z. \& X.M.) \\ + These authors contributed equally to this work.
}

Received: 3 March 2020; Accepted: 4 April 2020; Published: 9 April 2020

\begin{abstract}
Trifolium L., which belongs to the IR lacking clade (IRLC), is one of the largest genera in the Leguminosae and contains several economically important fodder species. Here, we present whole chloroplast (cp) genome sequencing and annotation of two important annual grasses, Trifolium alexandrinum (Egyptian clover) and T. resupinatum (Persian clover). Abundant single nucleotide polymorphisms (SNPs) and insertions/deletions (In/Dels) were discovered between those two species. Global alignment of T. alexandrinum and T. resupinatum to a further thirteen Trifolium species revealed a large amount of rearrangement and repetitive events in these fifteen species. As hypothetical $\mathrm{cp}$ open reading frame (ORF) and RNA polymerase subunits, ycf1 and rpoC2 in the cp genomes both contain vast repetitive sequences and observed high Pi values $(0.7008,0.3982)$ between T. alexandrinum and $T$. resupinatum. Thus they could be considered as the candidate genes for phylogenetic analysis of Trifolium species. In addition, the divergence time of those IR lacking Trifolium species ranged from 84.8505 Mya to 4.7720 Mya. This study will provide insight into the evolution of Trifolium species.
\end{abstract}

Keywords: chloroplast genome; Trifolium; divergence time; IR lacking; rearrangement; repetitive events

\section{Introduction}

Trifolium L. (Leguminosae, Fabaceae), one of the largest genera in the Leguminosae, contains several important fodder species, such as T. repens (white clover), T. pratense (red clover), T. alexandrinum (Egyptian clover), T. resupinatum (Persian clover) amongst others [1]. Trifolium species are also widely grown as green manure crops, and about 11 species, including $T$. alexandrinum and T. resupinatum, were introduced to the subtropical zone of east Asia and have been reported to be excellently adapted to saline-alkali soil thus useful for agricultural production [2]. T. alexandrinum is generally grown as an annual winter legume fodder crop in the Middle East, Mediterranean and the Indian 
subcontinent. Its aerial part can be used for cattle feed and the seeds are used as an antidiabetic treatment [3]. Furthermore, T. alexandrinum also contributes to soil fertility and improves soil physical characteristics [3]. T. resupinatum, an annual, prostrate or semi-erect branched legume, can supply highly palatable and nutritive pasture and hay [4]. What's more, it also has economic significance for the ornamental and landscape industries [4].

As an important part of plant organelles and photosynthetic organ, chloroplast (cp) has played an irreplaceable role in plants [5]. The cp genomes are not only essential for the study of plants light system for potentially improving the photosynthetic capacity and thus increasing plant yield, but are also commonly employed for phylogenic study for their maternal inheritance and highly conserved genomic structure [6]. The cp genome has a typically covalently closed circular molecule structure including a small single-copy region (SSC), a large single-copy region (LSC) and two almost identical inverse repeats (IRs) regions [5]. A typical cp genome contains approximately 130 genes. Many of them participate in photosynthesis, some others also encode proteins or function in regulating gene transcription [6].

Possessing the function of replication initiation, genome stabilization and gene conservation [7], the IR regions with the average length between $10 \mathrm{~Kb}$ to $76 \mathrm{~Kb}$ were found in almost families in the angiosperm plants and some gymnosperm and fern genus [8]. However, a lack of IRs was found in the clover genus (Trifolium) of the legume family (Leguminosae) and coniferous cp genomes, such as Medicago L., Melilotus Miller, Ononis L. and so on [2]. A previous study has shown that differential elimination of genes from the IR regions may result in IR lacking in Ulvophyceae [9]. Meanwhile, gene loss including $y c f 2$ and $p s b A$ lead to IR lacking from cp genomes of Cedrus wilsoniana and C. deodara [10]. However, what causes the IR lack of $\mathrm{cp}$ genomes in Trifolium species still remains to be elucidated.

The lack of IR generates a highly rearranged cp genome, thus experiencing gene losses and inversions in the SSC or LSC regions [11]. Furthermore, quadruple of repeated DNA compared to related legume species is found to typically exist in IR lacking subclover (T. subterraneum) based on previous studies [12]. However, this unusual repeat-rich $\mathrm{cp}$ genome structure was also reported in other IR lacking Trifolium species, such as T. repens, T. meduseum, T. semipilosum and so on [13]. Those repetitive structures might be related to the sequence rearrangement of cp genomes via intra homologous recombination [8] in some angiosperm lineages like the Campanulaceae [14]. However, what causes the repeat-rich cp genomes structures of the Trifolium species is still worth studying, although previous studies have suggested that it may be related to the nuclear genes [13].

Insights gained from cp genome sequences and structure have improved the revelation of variation among plant species and made significant contributions to phylogenetic analysis [6]. Leguminosae are accepted to have flourished since the Cretaceous period and the phylogenetic relationships among some Trifolium species were well estimated using 58 protein-coding genes in cp genomes [13]. However, two important annual Trifolium species, T. alexandrinum and T. resupinatum have not been included in any previous study. Variation among different species could provide a fascinating glimpse into the understanding of plant biology and diversity [6]. Here, cp genomes of T. alexandrinum and T. resupinatum were sequenced and annotated. We compared the sequence differences caused by nucleotide diversity $(\mathrm{Pi}), \mathrm{In} / \mathrm{Del}$ and repetitive sequences, as well as the evolution pressure reflected by non-synonymous/synonymous $(\mathrm{Ka} / \mathrm{Ks})$ between these two species. Furthermore, they were compared with further thirteen IR lacking congeneric species and divergent times were estimated. This study provides insights into the evolution of IR lacking cp genomes.

\section{Results}

\subsection{Features of the T. alexandrium and T. resupinatum $c p$ Genomes}

More than 20 million ReadSum (pair-end reads) were yielded from T. alexandrium and T. resupinatum, with the Q20 and Q30 (the percentage of bases whose mass value is greater than or equal to 20,30) higher than $94 \%$ and $87 \%$, respectively. We assembled them successfully based on the alignment of 
paired-end sequences to the reference of T. medeseum (Figure 1). The cp genomes of T. alexandrium and T. resupinatum were detected with a lack of IR and have a size of $148,545 \mathrm{bp}$ and $149,026 \mathrm{bp}$, respectively (Table 1). The GC content observed in the two cp genomes was 34.09\% and 33.80\% overall, and $37.05 \%$ and $36.64 \%$ in coding sequences (CDS). A total of 112 and 109 genes were consisted in the complete cp genomes of T. alexandrinum and T. resupinatum, which contains 31 and 37 tRNA, 75 and 66 mRNA, and 6 rRNA, and 13 and five genes possessing introns, respectively. In particular, there were two $r$ rn 16 genes in each of the Trifolium species with the unidentical sequences.

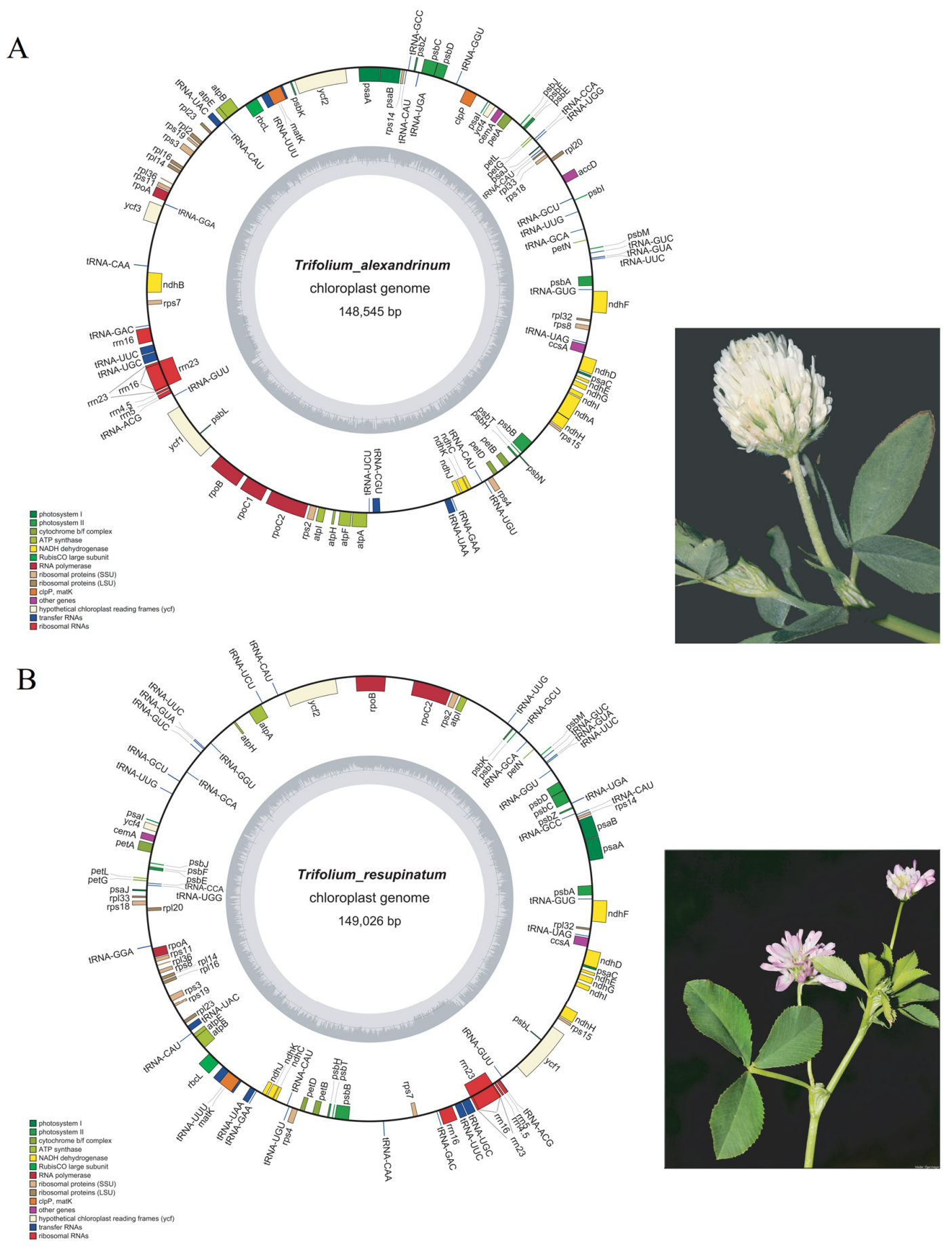

Figure 1. Gene maps of T. alexandrinum (A), T. resupinatum $\mathbf{( B )} \mathrm{cp}$ genomes and pictures of T. alexandrinum and T. resupinatum were shown right in the gene maps. Pictures were cited from the open website http://plants-of-styria.uni-graz.at. Genes drawn inside and outside of the circle are transcribed clockwise 
and counterclockwise, respectively. Genes belonging to different functional groups are color coded. The darker gray color and lighter gray color in the inner circle corresponds to the GC content and the AT content, respectively.

There were 46 genes related to photosynthesis in cp genomes of T. alexandrinum and T. resupinatum (Table 2), of which four genes $p s b N, a t p F, n d h A$ and $n d h B$ were specific for T. alexandrinum. These genes include the ones encoding subunits of Rubisco, subunits of photosystem I, subunits of photosystem II, subunits of ATP synthase, cytochrome b/f complex, c-type cytochrome synthesis and subunits of NADH dehydrogenase. Thirty-one genes were related to self-replication, including four ribosomal RNA genes and 27 transfer RNA genes, in which trnT-CGU was unique in T. alexandrinum. Besides, ten genes encoded ribosomal proteins and twelve were associated with transcription. Among them, $r p l 2$ and $r p o C 1$ were unique in T. alexandrinum. Furthermore, three genes $c l p P$, accD and ycf3 with other functions were particular for T. alexandrinum (Table S1).

Introns are generally not subject to natural selection thus theoretically accumulate more mutations than exons. In this study, a total of seven genes ( $a t p F, c l p P, n d h A, n d h B, r p o C 1, r p s 18$ and $t R N A-C G U)$ only contained an intron in T. alexandrinum (Table S1). Other five genes $t R N A-U A A, t R N A-U A C$, $t R N A-U G C, t R N A-U U C$ and $t R N A-U U U$ all had an intron in T. alexandrinum and T. resupinatum. The exons length of those five genes was more conserved compared with the intron. In particular, ycf3 had two introns in T. alexandrinum. 
Table 1. Comparison of the fifteen Trifolium species.

\begin{tabular}{|c|c|c|c|c|c|c|c|c|c|c|}
\hline \multirow{2}{*}{ Species } & \multirow{2}{*}{$\begin{array}{c}\text { Genome Length(bp) } \\
\text { Repetitive } \%\end{array}$} & \multicolumn{2}{|c|}{ GC Content (\%) } & \multirow{2}{*}{$\begin{array}{c}\text { Gene } \\
\text { Density }\end{array}$} & \multirow{2}{*}{ tRNA } & \multirow{2}{*}{ rRNA } & \multirow{2}{*}{ mRNA } & \multirow{2}{*}{ Genes } & \multirow{2}{*}{$\begin{array}{l}\text { Genes with } \\
\text { Introns }\end{array}$} & \multirow{2}{*}{$\begin{array}{l}\text { GenBank } \\
\text { Number }\end{array}$} \\
\hline & & cp Genome & CDS & & & & & & & \\
\hline T. alexandrinum & $148545 / 2.85 \%$ & 34.09 & 37.05 & $7.54 \times 10^{-4}$ & 31 & 6 & 75 & 112 & 13 & MN857160 \\
\hline T. resupinatum & $149026 / 2.69 \%$ & 33.80 & 36.64 & $7.31 \times 10^{-4}$ & 37 & 6 & 66 & 109 & 5 & MN857161 \\
\hline T. subterraneum & $144763 / 20.71 \%$ & 34.83 & 37.10 & $7.60 \times 10^{-4}$ & 30 & 4 & 76 & 110 & 16 & NC011828 \\
\hline T. meduseum & $142595 / 12.83 \%$ & 34.87 & 37.34 & $7.78 \times 10^{-4}$ & 30 & 4 & 77 & 111 & 15 & NC476730.1 \\
\hline T. pratense & $121178 / \mathrm{NA}^{*}$ & 34.63 & 36.94 & $7.43 \times 10^{-4}$ & 28 & 4 & 58 & 90 & 11 & KJ788290 \\
\hline T. repens & $132120 / 20.70 \%$ & 34.53 & 36.96 & $8.10 \times 10^{-4}$ & 31 & 4 & 72 & 107 & 16 & КС 894706.1 \\
\hline T.strictum & $125834 / 0.71 \%$ & 34.98 & 36.70 & $8.82 \times 10^{-4}$ & 31 & 5 & 75 & 111 & 18 & NC025745.1 \\
\hline T.aureum & $126970 / 5.60 \%$ & 34.86 & 36.81 & $8.51 \times 10^{-4}$ & 30 & 4 & 74 & 108 & 15 & KC894708.1 \\
\hline T.boissieri & $125740 / 1.05 \%$ & 35.24 & 36.83 & $8.75 \times 10^{-4}$ & 31 & 5 & 74 & 110 & 17 & NC025743.1 \\
\hline T.glanduliferum & $126149 / 0.78 \%$ & 34.90 & 36.70 & $8.72 \times 10^{-4}$ & 30 & 5 & 75 & 110 & 17 & NC025744.1 \\
\hline T. grandiflorum & $126149 / 5.60 \%$ & 37.20 & 35.82 & $8.80 \times 10^{-4}$ & 30 & 4 & 77 & 111 & 16 & NC_024034 \\
\hline T. hybridum & $134831 / 7.86 \%$ & 34.33 & 35.97 & $8.08 \times 10^{-4}$ & 31 & 4 & 74 & 109 & 17 & KJ788286 \\
\hline T. lupinaster & $135049 / 5.98 \%$ & 33.97 & 35.71 & $8.15 \times 10^{-4}$ & 30 & 4 & 76 & 110 & 15 & KJ788287 \\
\hline T. occidentale & $133780 / 4.64 \%$ & 36.34 & 35.91 & $8.00 \times 10^{-4}$ & 29 & 4 & 74 & 107 & 17 & KJ788289 \\
\hline T. semipilosum & $138194 / 10.55 \%$ & 36.31 & 35.81 & $7.89 \times 10^{-4}$ & 31 & 4 & 74 & 109 & 17 & KJ788291 \\
\hline
\end{tabular}

${ }^{*}$ The cp genome annotation of Trifolium pratense is incomplete, so the percentage of repetitive cannot be calculated [13]. 
Table 2. List of genes annotated in the cp genomes of T. alexandrinum and T. resupinatum.

\begin{tabular}{|c|c|c|c|c|c|c|c|}
\hline \multirow{2}{*}{$\begin{array}{c}\text { Category } \\
\text { Self-replication (31) }\end{array}$} & \multirow{2}{*}{$\begin{array}{c}\text { Function } \\
\text { Ribosomal RNA Genes } \\
\text { Transfer RNA genes }\end{array}$} & \multicolumn{6}{|c|}{ Name of Genes } \\
\hline & & $\begin{array}{l}\operatorname{rrn} 4.5 \\
\operatorname{trn} A-A C G \\
\operatorname{trn} G-G C C \\
\operatorname{trnL}-U A G \\
\operatorname{trnS}-G G A \\
\text { trnT-UGU }\end{array}$ & $\begin{array}{c}\operatorname{rrn5} \\
\operatorname{trn} A-G U C \\
\operatorname{trn} G-U U C^{*} \\
\operatorname{trn} L-U U U^{*} \\
\operatorname{trnS}-U G A \\
\operatorname{trn} V-G A C\end{array}$ & $\begin{array}{c}\operatorname{rrn} 16 \\
\operatorname{trn} A-G U U \\
\operatorname{trnG}-U U G \\
\operatorname{trnM}-C A U \\
\operatorname{trnT}-C C A \\
\operatorname{trn} V-U A C^{*}\end{array}$ & $\begin{array}{c}\operatorname{rrn} 23 \\
\operatorname{trn} A-U C U \\
\operatorname{trn} H-G U G \\
\operatorname{trn} P-G A A \\
\operatorname{trn} T-C G U^{*} \text { (ale) }\end{array}$ & $\begin{array}{l}\operatorname{trn} A-U G C^{*} \\
\operatorname{trnL-CAA} \\
\operatorname{trn} P-U G G \\
\operatorname{trn} T-G G U\end{array}$ & $\begin{array}{c}\operatorname{trnC} C-G C A \\
\operatorname{trnL}-U A A \\
\operatorname{trnS}-G C U \\
\operatorname{trnT} T-G U A\end{array}$ \\
\hline Ribosomal proteins (10) & Small subunit of ribosome (SSU) & $\begin{array}{c}r p s 2 \\
\text { rps14 }\end{array}$ & $\begin{array}{c}r p s 3 \\
r p s 15\end{array}$ & $\begin{array}{c}r p s 4 \\
r p s 18^{*} / \text { ale }\end{array}$ & $\begin{array}{c}\text { rps7 } \\
\text { rps19 }\end{array}$ & $r p s 8$ & rps11 \\
\hline $\begin{array}{c}\text { Photosynthesis related } \\
\text { genes (46) }\end{array}$ & Large subunit of Rubisco & $r b c L$ & & & & & \\
\hline & $\begin{array}{l}\text { Subunits of Photosystem I } \\
\text { Subunits of Photosystem II }\end{array}$ & $\begin{array}{c}p s a A \\
p s b A \\
p s b H \\
p s b N(\text { ale })\end{array}$ & $\begin{array}{c}p s a B \\
p s b B \\
p s b I \\
p s b T\end{array}$ & $\begin{array}{l}p s a C \\
p s b C \\
p s b J \\
p s b Z\end{array}$ & $\begin{array}{l}p s a I \\
p s b D \\
p s b K\end{array}$ & $\begin{array}{l}p s a J \\
p s b E \\
p s b L\end{array}$ & $\begin{array}{l}p s b F \\
p s b M\end{array}$ \\
\hline & $\begin{array}{l}\text { Subunits of ATP synthase } \\
\text { Cytochrome b/f complex } \\
\text { C-type cytochrome synthesis gene }\end{array}$ & $\begin{array}{l}\operatorname{atp} A \\
\operatorname{pet} A \\
\operatorname{ccs} A\end{array}$ & $\begin{array}{l}\text { atpB } \\
\text { petB }\end{array}$ & $\begin{array}{l}\text { atp E } \\
\text { petD }\end{array}$ & $\begin{array}{l}\operatorname{atpF} F^{*} \text { (ale) } \\
\operatorname{pet} G\end{array}$ & $\begin{array}{l}\operatorname{atpH} \\
\text { petL }\end{array}$ & $\begin{array}{l}\text { atpI } \\
\text { petN }\end{array}$ \\
\hline & Subunits of NADH dehydrogenase & $\begin{array}{c}n d h A^{*} \text { (ale) } \\
n d h G\end{array}$ & $\begin{array}{c}n d h B^{*} \text { (ale) } \\
n d h H\end{array}$ & $\begin{array}{l}n d h C \\
n d h I\end{array}$ & $\begin{array}{c}n d h D \\
n d h J\end{array}$ & $\begin{array}{l}n d h E \\
n d h K\end{array}$ & $n d h F$ \\
\hline Other genes (7) & $\begin{array}{c}\text { Maturase } \\
\text { Protease } \\
\text { Chloroplast envelope membrane } \\
\text { protein } \\
\text { Subunit of acetyl-CoA } \\
\text { Hypothetical open reading frames }\end{array}$ & $\begin{array}{c}\text { matK } \\
\operatorname{clp} P^{*} \text { (ale) } \\
\text { cemA } \\
\text { accD (ale) } \\
y c f 1\end{array}$ & $y c f 2$ & $y c f 3^{* *}$ (ale) & & & \\
\hline
\end{tabular}

Note: ${ }^{\prime}$, Genes containing a single intron; ${ }^{* *}$, Genes containing two introns; (ale), Genes that are particular for T. alexandrinum; ${ }^{* / a l e}$, Genes that only have an intron in T. alexandrinum. 


\subsection{Repeat Sequences Analysis}

Scattered repetitive sequences (palindrome repeats and direct repeats) and simple sequence repeats (SSRs) were analyzed respectively. A total of 1941 scattered repetitive sequences in the T. alexandrinum $\mathrm{cp}$ genome were annotated, which was greater than T. resupinatum (1250). The percentages of palindrome repeats (type $P, 50.49 \%$, Figure 2B) of T. alexandrinum were slightly larger than T. resupinatum $(46.4 \%)$. A total of 370 (Figure 2A) and 383 SSRs (sizes ranged from 8-81 bp and 8-36 bp) were predicted in T. alexandrinum and T. resupinatum and $30.54 \%$ and $23.24 \%$ of them were distributed in genic regions. In particular, the majority of SSRs were located in ycf1 (18 for T. alexandrinum and T. resupinatum), followed by rpoC2 (11 for T. resupinatum and 9 for T. alexandrinum). Mononucleotide repeats were dominant $(65.41 \%$ in T. alexandrinum and $74.93 \%$ in T. resupinatum), followed by trinucleotide repeats ( $25.68 \%$ in T. alexandrinum and $22.19 \%$ in T. resupinatum), in which the polyadenine repeats (poly A, $37.34 \%$ for T. resupinatum and $35.95 \%$ for T. alexandrinum) and polythymine (poly T, $36.55 \%$ for $T$. resupinatum and $37.84 \%$ for T. alexandrinum) were much more than guanine (G) or cytosine (C) repeats (less than $1.35 \%$ ). A total of 24 SSRs were identified to be shared by T. alexandrinum and T. resupinatum (Additional file2: Table S2; Figure 2A). The common repeat sequences larger than $30 \mathrm{bp}$ with the longest length of $117 \mathrm{bp}$ was showed in Figure 2C.
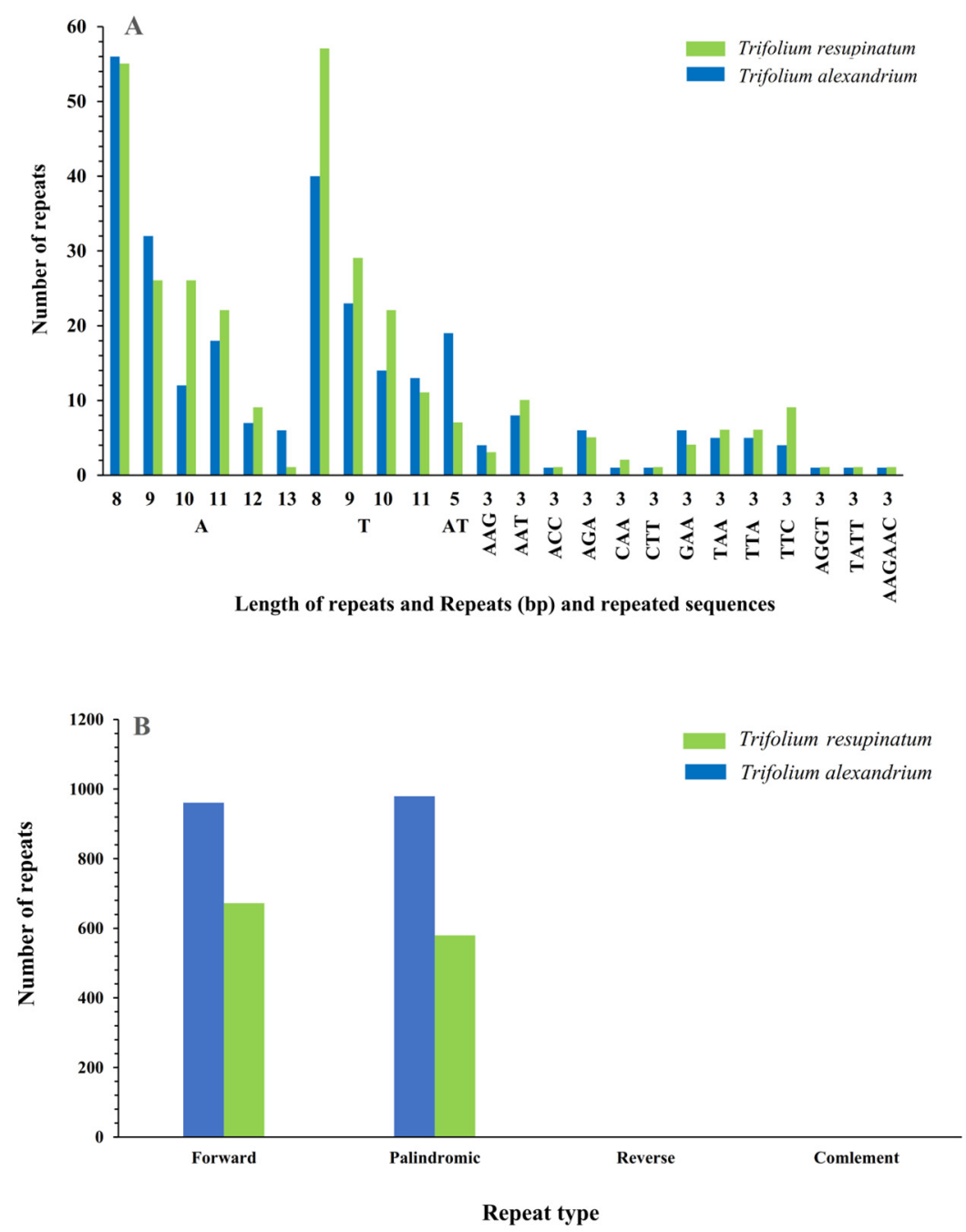

Figure 2. Cont. 


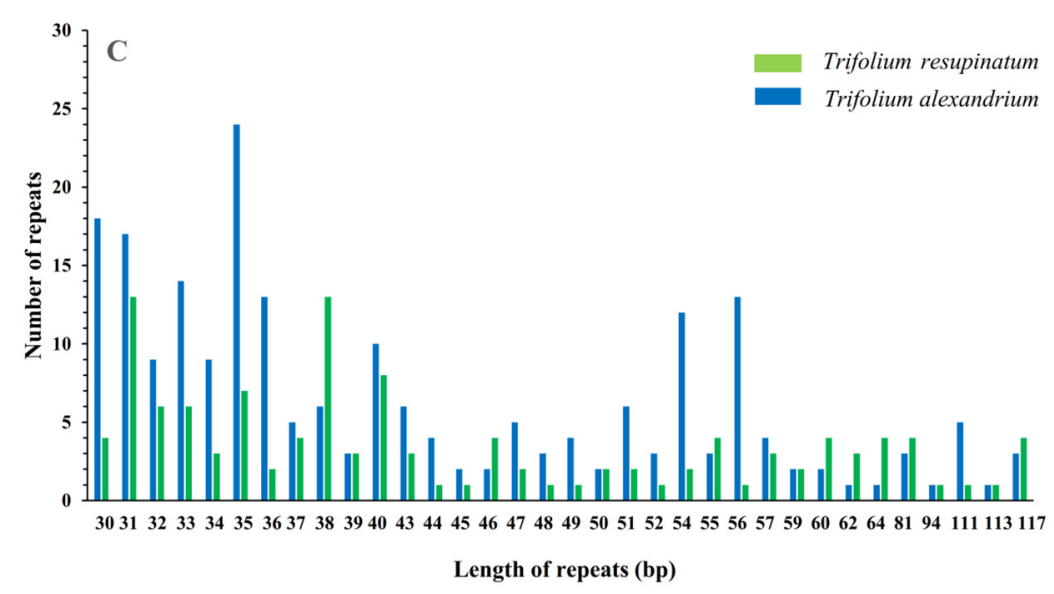

Figure 2. Repeating events of shared genes of T. alexandrinum and T. resupinatum. (A) Shared length of repeats and repeated sequences of T. alexandrinum and T. resupinatum; (B) Repeat type predicted in $T$. alexandrinum and T. resupinatum and $(\mathbf{C})$ Listing of shared repetitive sequences with more than $30 \mathrm{bp}$.

\subsection{Relative Synonymous Codon Usage Analysis}

Relative synonymous codon usage analysis (RSCU), which is considered to be a combination result of natural selection, species mutation and genetic drift, was analyzed (Additional file1: Figure S1; Additional file3: Table S3). The RSCU value for initiation codon AUG was 2.9745 in T. alexandrinum and 2.9721 in T. resupinatum. The values of three termination codons UAA, UAG and UGA were 1.6215, 0.5676 and 0.8109 in T. alexandrinum, and $1.5909,0.5454$ and 0.8637 in T. resupinatum. The codons with an RSCU value greater than one were considered to be a greater codon frequency. $46.97 \%$ (31 of 66, include three termination codons) of the codons were with the greater codon frequency both in $T$. alexandrinum and T. resupinatum, in whih $93.55 \%$ (29 of 31) prefers A or $\mathrm{U}$ in the third sites. In the other codons with RSCU values less than one (including one), $C$ or G were more common in the third position $(88.57 \%, 31$ of 35$)$.

\subsection{Ka/Ks, Single Nucleotide Polymorphisms (SNPs) and Insertions/Deletions (In/Dels)}

Single nucleotide polymorphisms (SNPs), mainly including transversion (Tv) and transition (Tn), along with insertions/deletions (In/Dels) could lead the non-synonymous (Ka) or synonymous (Ks) substitution. SNPs and In/Dels in every gene varied from 1 ( $n d h E$ and $p s a C$ ) to 677 (atpB) with a total of 8560. Additionally, more In/Dels, Tn and Tv were detected in intergenic regions $(5.66 \%, 17.11 \%$ and $38.70 \%$ ) than genic regions (3.05\%, 10.40\% and 25.08\%) (Figure 3; Additional file4: Table S4). The 66 shared protein-coding genes with variations were used to calculate the Ka and Ks (Additional file5: Table S5). The values of Ka and Ks ranged from 0 (ndhE, petD, psaI, $p s b A, p s b B$ and so on) to 3.0151 (rps4) and 0 (petG, petN, ndhD, psaJ, pabK, rpl23 and rpl36) to 2.9415 (rps8). Except for seven genes with $\mathrm{Ks}=0$, the 59 shared genes were used to calculate $\mathrm{Ka} / \mathrm{Ks}$, which varied from 0 ( $n d h E, p s b Z, p s b A, p s b J$ and so on) to 3.7723 (rps4, Figure 4), respectively. Seven genes including rps4, rpoC2, ndhG, ccs A, ndhF, $r p o A$ and $p s a C$ have $\mathrm{Ka} / \mathrm{Ks}$ values above one, implying positive selection on these genes. The Pi values calculated by 96 common genes of T. alexandrinum and T. resupinatum were from 0 to 0.7867 (trnl-CAU). Twenty-one genes had a Pi values of 0 , among which nineteen were tRNA. What's more, the nine genes with $\mathrm{Ka} / \mathrm{Ks}$ above one also possessed relatively high Pi values (Figure 5; Additional file6: Table S6). 


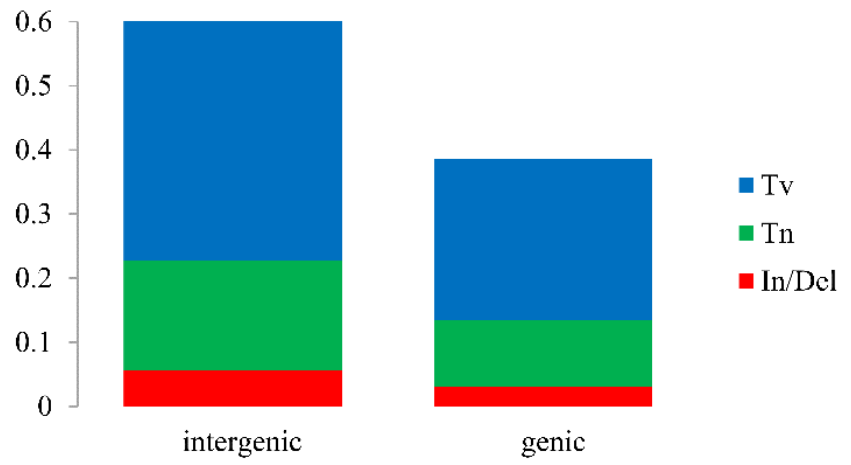

Figure 3. Transversion (Tv), transition (Tn) and Insert/Deletion (In/Del) were showed in intergenic and genic regions.

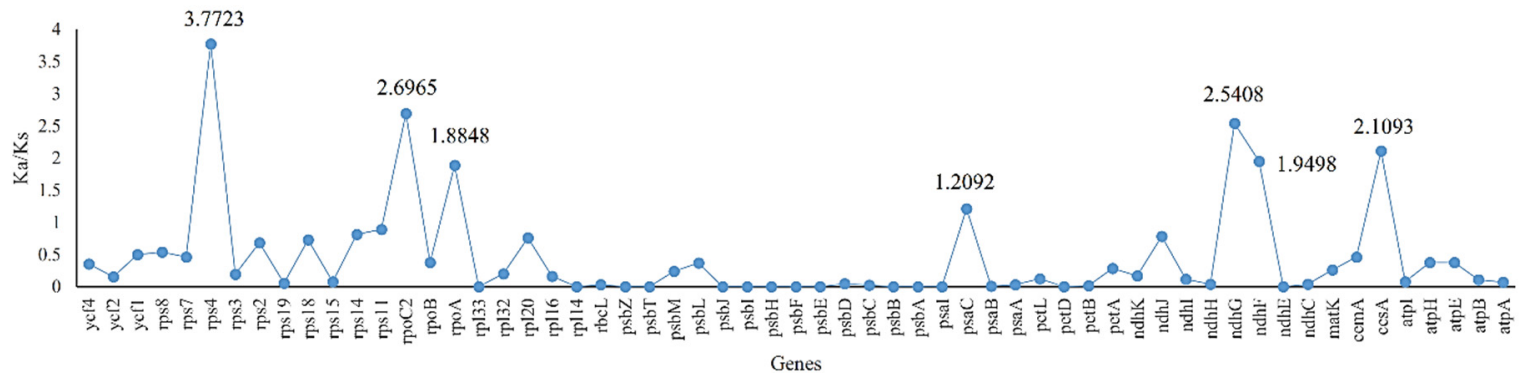

Figure 4. The synonymous/synonymous substitution rates $(\mathrm{Ka} / \mathrm{Ks})$ calculated using 59 shared genes in T. alexandrinum and T. resupinatum.

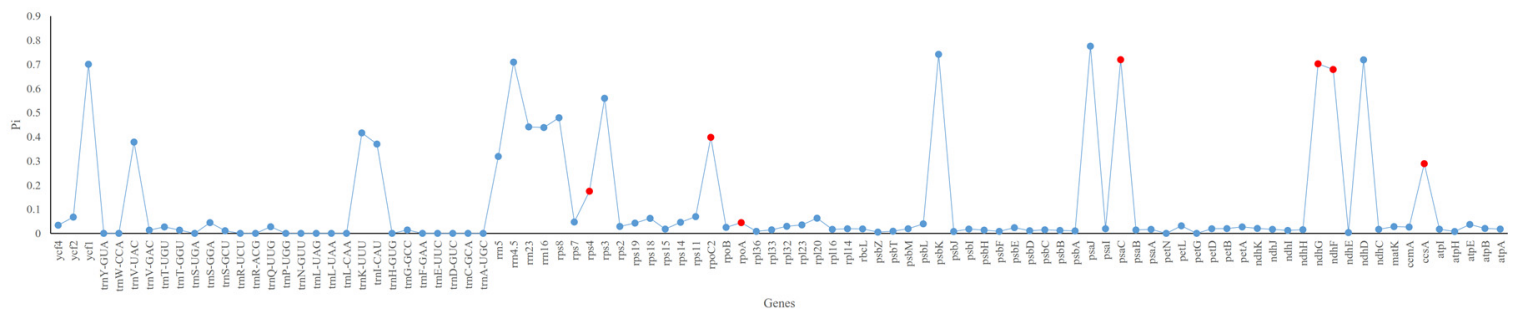

Figure 5. The nucleotide diversity (Pi) computed using 96 common genes of T. alexandrinum and T. resupinatum. Genes with $\mathrm{Ka} / \mathrm{Ks}$ values more than one were red coded.

\subsection{Whole cp Genome Comparison with Other Trifolium Species}

In order to examine the sequence divergence of Trifolium genus and further shed light on the evolutionary events, such as gene mutation, rearrangement and gene loss, cp genomes of fifteen IR lacking species (T. grandiflorum, T. hybridum, T. lupinaster, T. occidentale, T. semipilosum, T. aureum, T. boissieri, T. glanduliflerum, T. strictum, T. repens, T. pratense, T. subterraneum, T. meduseum, T. alexandrinum and $T$. resupinatum) were compared. The results showed that the size of $\mathrm{cp}$ genomes of these IR lacking species ranged from $121,178 \mathrm{bp}$ (T. pratense) to $149,026 \mathrm{bp}$ (T. resupinatum), with an average of 134,062 bp (Table 1). The GC content of those fifteen species changed from $33.80 \%$ to $37.20 \%$ in whole cp genome with the mean value of $34.99 \%$, and $35.71 \%$ to $37.34 \%$ in CDS with the mean of $36.55 \%$. Only minor variations were detected in the total numbers of genes, tRNA and mRNA among the selected species. T. pratense possessed the smallest numbers of tRNA (28), mRNA (58) and total number of genes (90). Furthermore, abundant gene rearrangements at the cp genome level were detected among fifteen Trifolium species using MAUVE program and the T. resupinatum as the reference sequence (Figure 6). 


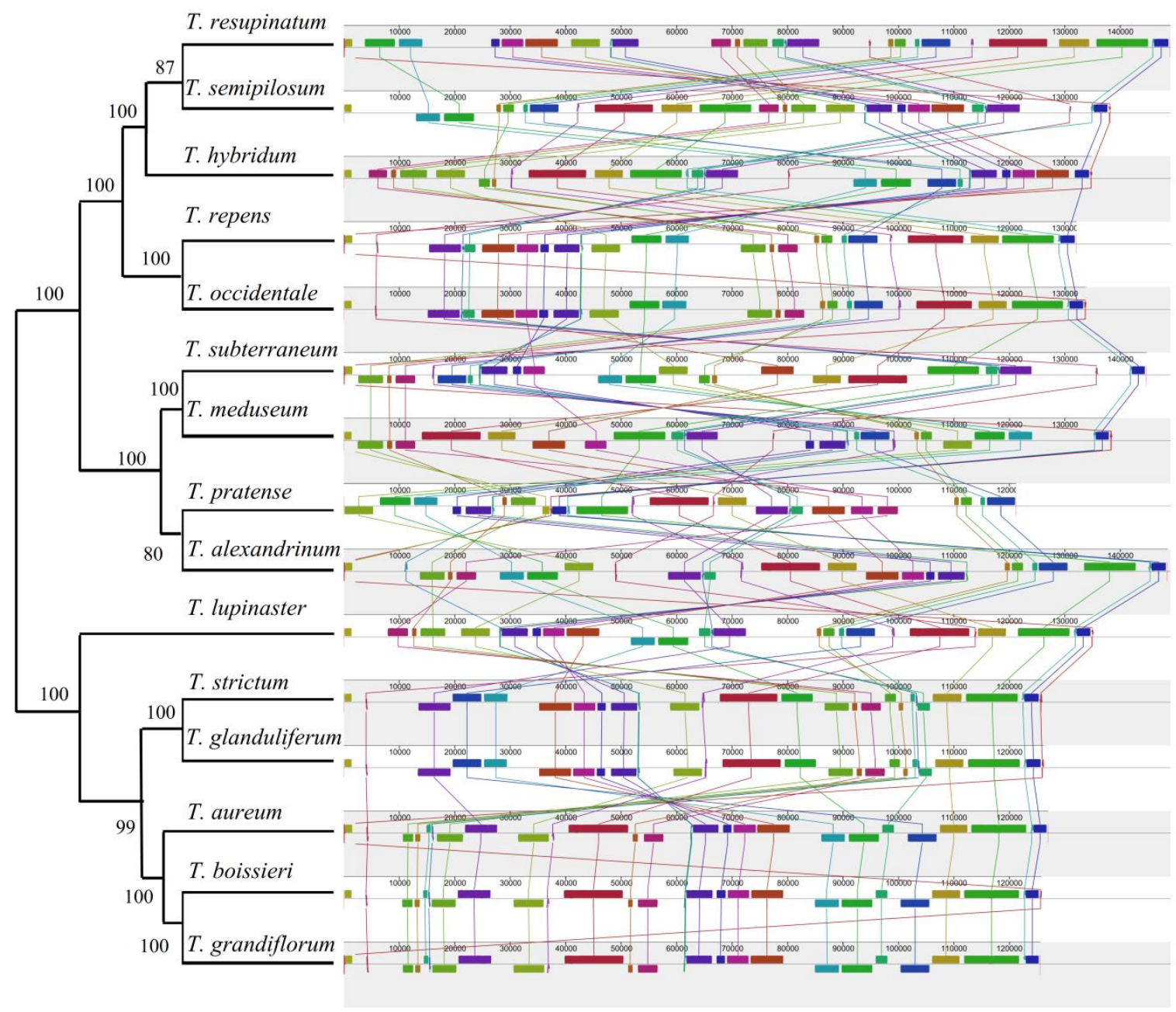

Figure 6. Synteny comparison of fifteen Trifolium chloroplast genomes with the reference of $T$. resupinatum using Mauve. Rectangular blocks with the same color indicate collinear regions.

\subsection{Phylogenetic Divergence Time Estimation}

The 41 protein-coding genes shared in cp genomes of the 25 species ( 23 of Papilionoideae, one of Caesalpinioideae and one of Mimosaceae) were subjected to phylogeny analysis and divergence times estimation (Figure 7A). The topological structure of phylogenetic tree was almost consistent with the classification of Leguminosae with strong bootstrap support. Three subfamilies of Leguminosae, Papilionoideae, Caesalpinioideae and Mimosaceae were clearly separated. Furthermore, two genes ycf1 and rpoC2, which both contain vast repetitive sequences and high Pi values $(0.7008,0.3982)$ between T. alexandrinum and T. resupinatum, were also used to construct the phylogenetic trees. The result showed that the topological structure of the phylogenetic relationship of Trifolium species based on ycf1 (Figure 7B) and rpoC2 (Figure 7C) was almost in accordance with the phylogenetic tree constructed using 41 shared genes. Each Section of Trifolium was clearly divided based on ycf1 and rpoC2 genes. The Trifolium species of "refractory clade" (including Section Lupinaster, Trifolium, Tricocephalum, Vesicastrum and Trifoliastrum) were grouped together in Figure 7C. In Figure 7B, however, Section Trifolium, Tricocephalum, Vesicastrum and Trifoliastrum were grouped into one clade, and another clade consisted of Section Lupinaster, Paramesus and Subg. Chronosemium. Trifolium species split from Medicago species during the Early Cretaceous (116.1575 Mya) and the divergence time of those fifteen IR lacking Trifolium species ranged from 84.8505 Mya to 4.7720 Mya (Figure 7). 

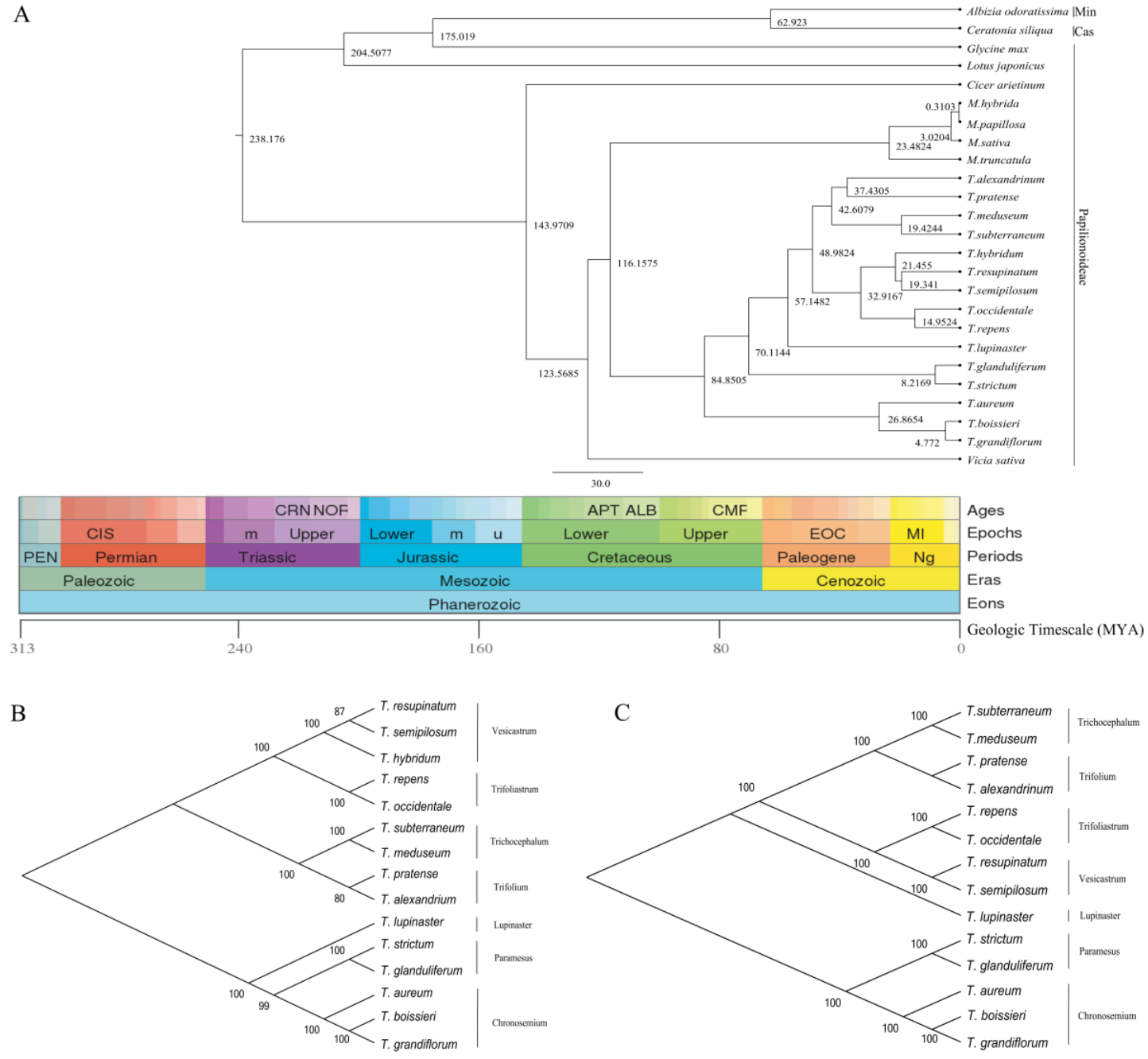

Figure 7. (A) BEAST chronogram of the 25 Leguminosae species based on the 41 common protein-coding genes and the phylogenetic trees constructed using rpoC2 gene (B) and ycf1 gene (C, ycf1 gene was absent in T. hybridum). Geologic timescale was obtained from TIMETREE, time is shown in millions of years (MYA). Min, Mimosaceae; Cas, Caesalpinioideae. The over 50\% bootstrap support values were showed in each main branch.

\section{Discussion}

\subsection{Genome Feature of T. alexandrinum and T. resupinatum and Comparison with Other IR Lacking} Trifolium Species

In this study, we sequenced and annotated cp genomes of two IR lacking species T. alexandrinum and $T$. resupinatum, identified the repeats and hotspot genes within the $\mathrm{cp}$ genomes, and constructed the phylogenetic tree along with other cp genomes. Our results added information about cp genomes of Trifolium species and provided new insights into the evolution study of IR lacking species.

The two cp genomes sequenced in this study revealed 75 and 66 protein-coding genes in T. alexandrinum and T. resupinatum, respectively (Table 1). There were nine unique genes in the T. alexandrinum $\mathrm{cp}$ genome which were absent in T. resupinatum, which might have been transferred from the $\mathrm{cp}$ genome to the nucleus genome of T. resupinatum in the evolutionary process of the species. A similar result was revealed in tobacco with an absent $a c c D$ gene, which was essential for leaf development $[15,16]$. The rpl2 gene, which was absent in T. resupinatum, has been completely or partially transferred to the nucleus genome of some legumes like soybean and Medicago [17]. Besides, the loss of two $n d h$ genes $(n d h A$ and $n d h B)$ was usually related to the nutritional status and rearrangement in 
most angiosperm species [18]. Although gene loss of atpF [19], psbN [19], rpoC1 [19] and ycf3 [20] was also found in other species, however, the detailed reason for that gene loss remained to be explained.

Compared to other IR containing cp genomes of angiosperms, the number of protein-coding genes of Trifolium species is less conserved [21,22]. It might be related to the fact that IR lacking will lead to an extensively arranged $\mathrm{cp}$ genome thus causing diverse genes loss [11]. According to Millen et al. [23], the vast majority of cp genomes of angiosperms held in shared 74 coding-protein genes but other five genes $(a c c D, y c f 1, y c f 2, r p l 23$ and $\inf A)$ only existed in some specific species. infA gene, which codes for translation initiation factor 1 (IF1), was defunct in all the listed fifteen Trifolium species. Considered as the most transferable gene in cp genome, infA was in existence in about 24 angiosperm lineages including Trifolium species, and related Medicago species [24,25]. It is worth noting that there are two rrn16 gene in each of Trifolium species sequenced in this study, and this phenomenon was also reported in cp genomes of T. strictum [13] and T. glanduliferum [13]. Furthermore, we also found that one of the $r r n 16$ and $r r n 23$ was partially overlapped. Indeed, no similar phenomenon was found in other Trifolium species. Previous studies have shown that Cyanobacteria, Chlamydomonas reinhardtii, Cyanophora paradoxa, Zea mays, Oryza sativa and Arabidopsis thaliana can start and stop transcription anywhere in the cp genome [26]. Chloroplasts are known to originate from ancient Cyanobacteria, this transcription property may be conserved in some species like T. alexandrinum and T. resupinatum, so that the rRNA genes of those two species may gain potential transcription ability. On the other hand, the cp genomes of most plant species are small and in order to avoid costs, genes overlapping happened. The Ycf1 (hypothetical chloroplast reading frame no. 1) gene, generally with the premature stop codons in the CDS thus be defined as pseudogene in other angiosperm [27], has undergone processes of accelerated mutation rate, decreased GC content, and decreased secondary structure stability [28]. In this study, the ycf1 gene detected in all the fourteen Trifolium species (except T. hybridum) contains a normal stop codon and is able to code protein. Two genes ycf4 (hypothetical chloroplast reading frame no. 4) and rps16 (ribosomal protein S16), which were found in most cp genomes of angiosperm and some relic plant like Amborella trichopoda [29], are not present in the two Trifolium species cp genomes sequenced in this study, and rps16 is not present in all the fifteen Trifolium species. The rps8 (ribosomal protein S8) gene was found without stop codons in Medicago truncatula and M. sativa [25], while it possesses a stop codon in the fifteen Trifolium cp genomes. In the gene $n d h B$, no internal stop codon was detected in the fourteen (except $T$. resupinatum) Trifolium cp genomes, which is inconsistent with many legume cp genomes whose $n d h B$ gene contains an internal stop codon [25].

\subsection{Relative Synonymous Codon Usage Analysis (RSCU)}

The unequal using frequencies of synonymous codons detected in most sequenced genomes was termed synonymous codons usage bias [30], and is now considered crucial in shaping gene expression and cellular function [31]. RSCU indicates the relative probability of a particular codon encoding the synonymous codon of the corresponding amino acid. In this study, $93.5 \%$ of the codons were found prefer A/U in third position, similar to that of M. sativa [25] and Gossypium [32]. This phenomenon could be attributed to the fact that dicotyledon prefers to the $\mathrm{A} / \mathrm{U}$-end codons and manifests a potential force in molecular evolution of Trifolium species: mutation and natural selection.

\subsection{SSRs and Large Repeat Sequences}

Given a matrilineal inheritance feature, rich number of tags and low frequency of genetic recombination, cpSSRs (chloroplast simple sequence repeats) are considered an efficient molecular marker in genetic variety analyzing, population structure studying, species identification and phylogeny analysis [33]. The SSRs identified in T. alexandrinum and T. resupinatum were poly(A)/(T), which was consistent with the majority of plant family [34-36]. Although there have many studies reported on the application of cpSSRs in plant genetic diversity analysis, the important potential of cpSSRs in studying the ecological and evolutionary processes of wild materials of plants and their related species still need to be recognized [37]. Therefore, the cpSSRs of the two Trifolium species detected in this study can be 
used to evaluate genetic relationships among different species and to detect polymorphism of Trifolium species and their relatives at the population level.

Repetitive sequences related to the continuously self-replicating of genetic material in the process of evolution, thus indicating the greatly expanded and enriched genetic information [38]. The present study revealed a relatively high repetitive percentage $(7.325 \%$, Table 1$)$ in the cp genomes of fifteen IR lacking species, which was higher than IR lacking Tydemania expeditionis $(0.4 \%)$ and Bryopsis plumose $(2.4 \%)$ [7]. The number of repeated sequences in the cp genome are associated with rearrangement in some species [14]. However, the driving force of the repetitive sequence was predominantly related to nuclear genes and genomic recombination [12], such as homologous recombination and microhomology-mediated break-induced replication acting on more than $50 \mathrm{bp}$ and less than $30 \mathrm{bp}$ repeats, respectively. Known as "hotspots" for variation [39], ycf1 and rpoC2 possessed high values of $\mathrm{Pi}$ (Figure 5) and the majority of repetitive sequences in T. alexandrinum and T. resupinatum. Therefore, these two genes could have suffered from selection pressure and could be used for phylogenetic analysis and population genetic study of Trifolium species.

\subsection{Sequence Divergence and Hotspots}

Point mutation was generally more common than frame shift for natural mutation [40]. As expected, more SNPs (21963, 6618 Tn and 15345 Tv; Additional file4: Table S4) than In/Del (2097) were found between $T$. alexandrinum and T. resupinatum. What's more, $60 \%$ of them occurred in intergenic regions, which was consistent with the hypothesis that CDS had a slower rate of evolution compared with CNS [41]. Furthermore, minor SNPs (159 between Oryza sativa and O. nivara [42], 330 between Citrus sinensis and C. aurantiifolia [43] and 231 between Machilus yunnanensis and M. balansae [44]) were identified in IR containing species, which were exceptionally smaller than the SNPs between two IR lacking species T. alexandrinum and T. resupinatum calculated in the present study. As an important structure in stabilizing cp genome, the IR region can prevent the genome mutating by selective force [45]. Thus the observed abundant SNPs/Indels in T. alexandrinum and T. resupinatum are not surprising.

The comparison between the $\mathrm{Ka}$ and $\mathrm{Ks}$ of genes is an important measure of molecular evolution [46]. Most genes were subjected to neutral selection and purification selection; however, there are also limited genes whose rate of Ka is higher than that of Ks because the function of the gene has been dramatically changed, called Darwinian positive selection [47]. Lacking one IR region is believed to directly enhance the nucleotide substitution rate of the single repeat sequence. Previous studies have shown that in the IR lacking cp genome, the nucleotide substitution rate in the remaining repeat region is comparable to that of the single repeat region, which is 2.3 times higher than that in the IR containing cp genome [48]. Here, seven protein-coding genes in the cp genomes of T. alexandrinum and T. resupinatum ( $r p s 4, r p o C 2, n d h G, c c s A, n d h F, y c f 1$ and $p s a C$ ) have a high ratio of Ka to Ks, which is led by high values of Ka but extremely low values of Ks, and could imply that they are under positive selections. rps4 [49] and $r p o C 2$ [50] have been reported to be under positive selection in previous studies. However, beneficial mutations might be fixed in those genes and, thus, reduce genetic polymorphism at selected sites [51].

In general, there is a strong correlation between the presence of IR and structurally stabilization of cp genomes. Substantial rearrangement was usually found in cp genomes lacking IR [13]. Among those IR lacking species of Leguminosae such as alfalfa, subclover, pea, and so forth, some are structurally stable and have not been rearranged, some undergo intermediate rearrangements, while others experienced a series of complex rearrangements [13]. This study found abundant rearrangements within fifteen cp genomes of IR lacking species of Trifolium (Figure 6). According to Palmer and Thompson [8], IR could prevent the rearrangement of cp sequence to some extent, so the rearrangement probability will be increased in the species lacking IR, this could be why there are many rearrangement events detected among those fifteen Trifolium species [8]. However, lacking IR leading to increased rearrangement is only one of the explanations. The repeats, acting as a locus of recombination within 
homologous genes, along with transposable elements (TEs), have been suggested as a reasonable mechanism for highly-rearranged cp genomes of Trifolium species [8].

\subsection{Phylogeny Analysis and Divergence Time}

The topological structure of other thirteen Trifolium species using 41 protein coding genes in this study was generally in agreement with the report of Sveinsson and Cronk [13] by 58 protein coding genes. In addition, the phylogenetic location of tested T. alexandrinum and T. resupinatum was confirmed (Figure 7). Furthermore, T. alexandrinum and T. pratense, both belonging to Trifolium Sect. Trifolium, were clustered together though T. alexandrinum and T. subterraneum were grouped together in Malaviya's study based on isozyme data [52]. Three IR lacking species T. boissieri, T. grandiflorum and T. aureum were predicted to differentiate with other twelve species in the late Cretaceous period, then another two IR lacking species T. strictum and T. glanduliferum were further diverted at about 8 Mya. In late Cretaceous period, violent crustal movement and sea-land changes led to a flourished development of angiosperms and IR lacking species might form at the same time. It looks as if the ancestor of some IR lacking species had gone through a battery of evolutionary alternation (including high rearrangement and repetition) and the precise mechanism of such an evolutionary pattern is underway to illuminate.

\section{Methods}

\subsection{Plant Material, DNA Isolation and Sequencing}

Plant seeds of T. alexandrinum ( $\mathrm{cv}$ 'Elite II') and T. resupinatum ( $\mathrm{cv}$ 'Laser') were kindly provided by Barenbrug (Queensland, Australia) then germinated in a growth chamber $\left(25^{\circ} \mathrm{C}, 300 \mu \mathrm{mols} \cdot \mathrm{m}^{2} \cdot \mathrm{s}^{-1}\right.$; 16-h photoperiod). Total DNA was extracted from $50 \mathrm{mg}$ of fresh leaves following the Plant DNA Isolation Kit (Tiangen, Beijing, China). Sheared low molecular weight DNA fragments were used to construct paired-end (PE) libraries according to protocol of Illumina manual (San Diego, CA, USA). Completed libraries were pooled and sequenced in the Illumina NovaSeq platform with PE150 sequencing strategy and $350 \mathrm{bp}$ insert size.

\section{2. cp Genome Assembly, Annotation and Visualization}

The raw read data for two Trifolium species were filtered according to the following criteria-reads of less than $5 \%$ unidentified nucleotides and more than $50 \%$ of their bases with a quality score of $>20$ were retained. With the reference genome of T. meduseum [12] (National Center for Biotechnology Information, NCBI number KJ 788288), the cp DNA were assembled as follows. In order to decrease the difficulty of sequences assembly, filtered reads (clean data) were aligned to the cp genome database built by Genepioneer Biotechnologies (Nanjing, China) using Bowtie2 v 2.2.4 [53] and SPAdes v3.10.1 [54] to acquire SEED sequences then obtained contigs by kmer iterative extend seed. Contigs, whose E-values were less than $1 \times 10^{-5}$, Identities values were close to $100 \%$ and Gaps were close to 0 by a BLAST research in NCBI with the data set including T. meduseum [12], T. pratense [13], T. repens [12] and T. subterraneum [20], were obtained. Then the contigs were connected as scaffolds using SSPACE v 2.0 [55] followed by gap filling using Gapfiller v 2.1.1 [56] until the complete chloroplast genome sequence was recovered.

The results of CDS and rRNA were obtained using BLAST V 2.2.25 and HMMER V3.1 b2 and the cp genome database of NCBI. ARAGORN V 1.2.38 [57] and tRNAscan-SE search server (http://lowelab.ucsc.edu/tRNAscan-SE/, [58]) were used to predict and further check tRNA. Finally, the consensus annotation was obtained via Geneious (https://www.geneious.com, [59]) and visualized in OGDRAW (https://chlorobox.mpimp-golm.mpg.de/OGDraw.html, [60]). 


\subsection{The Relative Synonymous Codon Usage Analysis (RSCU) and Simple Sequence Repeats (SSRs) Prediction}

The RSCU was analyzed using MEGA v7.0 to reflect the relative preference of a particular base encoding the corresponding amino acid codon [61]. Values of RSCU over one were considered to be a greater codon frequency. SSRs with the same repeats units and times and distributed in the genic regions were considered as shared repeats, the repetitive sequences were distinguished using VMATCH V2.3.0 (http://www.vmatch.de/) and MISA v1.0 (http://pgrc.ipk-gatersleben.de/misa/misa.html) based on the genomic data, which was also utilized to determine the mono-, di-, tri-, tetra-, penta- and hexa- nucleotides.

\subsection{Sequence Variation Analysis and $\mathrm{Ka} / \mathrm{Ks}$}

Whole $\mathrm{cp}$ genome alignment and collinearity analysis of sequenced species herein along with further thirteen IR-lacking Trifolium species, namely T. grandiflorum (NC_024034, [13]), T. hybridum (KJ788286, [13]), T. lupinaster (KJ788287, [13]), T. occidentale (KJ788289, [13]), T. semipilosum (KJ788291, [13]), T. strictum (NC025745.1, [13]), T. aureum (KC894708.1, [12]), T. boissieri (NC025743.1, [13]), T. glanduliferum (NC025744.1, [13]), T. subterraneum (NC011828, [20]), T. meduseum (NC476730.1, [13]), T. pratense (KJ788290, [13]) and T. repens (KC894706.1, [12]) was implemented using Mauve [62]. Furthermore, the common genes and shared protein-coding genes of T. alexandrium and T. resupinatum tested in the present study were utilized for nucleotide diversity (Pi) and $\mathrm{Ka} / \mathrm{Ks}$ calculation. $\mathrm{Ka} / \mathrm{Ks}$, which was generally considered to be a reflection of selection pressures, was computed via KaKs_Calculator v2.0 [63]. Pi, which could be used to estimate the degree of nucleotide sequences variation and further provide potential molecular markers for population genetics, was calculated using VCFTOOLS [64] after sequences alignment of the common genes by MAFFT version 7.017 [65]. Finally, single nucleotide polymorphisms (SNPs) and insertions/deletions (In/Dels) of T. alexandrium and T. resupinatum were also identified using Mafft program [65].

\subsection{Divergence Time Estimates}

The 41 common genes sequence of fifteen Trifolium species and another ten Leguminosae species, including Lotus japonicus (AP002983.1), Glycine max (NC_007942.1), Cicer arietinum (NC_011163.1), Ceratonia siliqua (NC_026678.1), Albizia odoratissima (NC_034987.1), Medicago truncatula (KF241982.1), M. sativa (KU321683.1), M. papillosa (NC_027154.1), M. hybrida (NC_027153.1) and Vicia sativa (NC_027155.1) were first blasted using MEGA [61] then the alignment file was utilized to assess the divergence time using BEAST v 1.7.3 package [66] with the Bayesian method. GTR + G + I substitution model with a strict clock model and Yule model for Priors tree were applied for BEAUti along with MCMC analysis setting as follows, 10,000,000 of Chain length, 1000 of Tracelog, 1000 of screenlog, 1000 of treelog.t: tree. The assessment of results was executed in Tracer v 1.5 (http://www.beast.bio.ed.ac.uk/) to confirm that the value of effective sample size (ESS) was greater than 200. Finally, the tree file obtained from TreeAnnotator was visualized in Figtree v1.4.3 (http://tree.bio.ed.ac.uk/software/figtree/). Furthermore, phylogenetic trees of the fifteen Trifolium species based on ycf1 gene and rpoC2 gene were constructed under Maximum Composite Likelihood method with 1000 bootstrap replications using MEGA v7.0 [61].

\section{Conclusions}

cp genomes of T. alexandrinum and T. resupinatum, which belong to inverted-repeat-lacking clade (IRLC), were sequenced and annotated in present study and were compared with the cp genomes of other thirteen IR lacking Trifolium species reported previously. The results revealed abundant SNP and In/Del in T. alexandrinum and T. resupinatum cp genomes and high variation in CDS and abundant rearrangement within Trifolium genus. This valuable information will provide insight into the evolution of IR lacking species. 
Supplementary Materials: The following are available online at http://www.mdpi.com/2223-7747/9/4/478/s1, Figure S1. The relative synonymous codon usage (RSCU) for the T. alexandrinum and T. resupinatum. Figure S2. The assembly sequence genomic coverage maps of T. alexandrinum and T. resupinatum. Table S1. Location and length of intron-containing genes in the chloroplast genomes of T. alexandrinum and T. resupinatum. Table S2. The shared repeats of T. alexandrinum and T. resupinatum. ${ }^{*}$ means the shared location for T. alexandrinum and T. resupinatum, res means locations particular for T. resupinatum, the numbers of "Number" mean number of repeats in T. alexandrinum and T. resupinatum, respectively. Table S3. The relative synonymous codon usage (RSCU) analyzed using CodonW. Table S4. Transversion (Tv) and transition (Tn) were detected between T. alexandrinum and T. resupinatum. Table S5. The synonymous/synonymous substitution rates $(\mathrm{Ka} / \mathrm{Ks})$ calculated using 59 shared genes in T. alexandrinum and T. resupinatum. Table S6. The nucleotide diversity (Pi) computed using 96 common genes of T. alexandrinum and T. resupinatum.

Author Contributions: Conceptualization, X.L. and Y.P.; Data curation, Y.X. (Yanli Xiong) and Y.X. (Yi Xiong); Formal analysis, Y.X. (Yanli Xiong), Y.X. (Yi Xiong) and J.Y.; Funding acquisition, X.M.; Investigation, J.H.; Methodology, J.H., J.Y. and Y.P.; Project administration, X.L.; Resources, Q.Y., Z.D. and X.Z.; Supervision, Q.Y.; Validation, J.Z.; Visualization, J.Z. and Z.D.; Writing-original draft, Y.X. (Yanli Xiong) and Y.X. (Yi Xiong); Writing-review \& editing, X.Z. and X.M. All authors have read and agreed to the published version of the manuscript.

Funding: This research was supported by the earmarked fund for Modern Agro-industry Technology Research System (No. CARS-34) and National Natural Science Foundation of China (3177131276).

Acknowledgments: We thank test support of laboratory staff in the Department of Grassland Science, Animal Science and Technology College, Sichuan Agricultural University.

Conflicts of Interest: The authors declare that they have no competing interests.

Availability of Data and Materials: The annotated chloroplast genomes of T. alexandrinum and T. resupinatum have been deposited in the NCBI GenBank with the accession numbers MN857160 and MN857161.

\begin{tabular}{ll}
\multicolumn{2}{l}{ Abbreviations } \\
cp & Chloroplast; \\
IRs & inverted-repeats; \\
IRLC & IR lacking clade; \\
SNP & single nucleotide polymorphisms; \\
In/Dels & insertions/deletions; \\
ORF & open reading frame; \\
SSC & small single-copy region; \\
LSC & large single-copy region; \\
NGS & next generation sequencing; \\
Pi & nucleotide diversity; \\
Ka & non-synonymous; \\
Ks & synonymous; \\
SSRs & simple sequence repeats; \\
RSCU & the relative synonymous codon usage analysis; \\
Tv & transversion; \\
Tn & transition; \\
CDS & coding sequences; \\
CNS & non-coding sequences; \\
UTR & untranslated regions \\
\end{tabular}

\section{References}

1. Sabudak, T.; Guler, N. Trifolium L.-A review on its phytochemical and pharmacological profile. Phytother. Res. 2009, 23, 439-446. [CrossRef] [PubMed]

2. Ellison, N.W.; Liston, A.; Steiner, J.J.; Williams, W.M.; Taylor, N.L. Molecular phylogenetics of the clover genus (Trifolium-Leguminosae). Mol. Phylogenet. Evol. 2006, 39, 688-705. [CrossRef] [PubMed]

3. Badr, A.; El-Shazly, H.H.; Watson, L.E. Origin and ancestry of egyptian clover (Trifolium alexandrinum L.) as revealed by AFLP markers. Genet. Resour. Crop Evol. 2008, 55, 21-31. [CrossRef]

4. Nazir, M.; Shah, F.H. Studies on persian clover (Trifolium resupinatum). Plant Food Hum. Nutr. 1985, 35, 57-62. [CrossRef] 
5. Douglas, S.E. Chloroplast origins and evolution. In The Molecular Biology of Cyanobacteria; Springer: Dordrecht, the Netherlands, 1994; pp. 91-118.

6. Daniell, H.; Lin, C.S.; Yu, M.; Chang, W. Chloroplast genomes: Diversity, evolution, and applications in genetic engineering. Genome Biol. 2016, 17, 130-134. [CrossRef] [PubMed]

7. Turmel, M.; Otis, C.; Lemieux, C. Divergent copies of the large inverted repeat in the chloroplast genomes of ulvophycean green algae. Sci. Rep. 2017, 7, 1-14. [CrossRef]

8. Palmer, J.D.; Osorio, B.; Aldrich, J.; Thompson, W.F. Chloroplast DNA evolution among legumes: Loss of a large inverted repeat occurred prior to other sequence rearrangements. Curr. Genet. 1987, 11, 275-286. [CrossRef]

9. Turmel, M.; Otis, C.; Lemieux, C. Mitochondrion-to-chloroplast DNA transfers and intragenomic proliferation of chloroplast group II introns in Gloeotilopsis green algae (Ulotrichales, Ulvophyceae). Genome Biol. Evol. 2016, 8, 2789-2805. [CrossRef]

10. Wu, C.S.; Wang, Y.N.; Hsu, C.Y.; Lin, C.P.; Chaw, S.M. Loss of different inverted repeat copies from the chloroplast genomes of Pinaceae and Cupressophytes and influence of heterotachy on the evaluation of Gymnosperm phylogeny. Genome Biol. Evol. 2011, 3, 1284-1295. [CrossRef]

11. Kaila, T.; Chaduvla, P.K.; Rawal, H.C.; Saxena, S.; Tyagi, A.; Mithra, S.V.; Gaikwad, K. Chloroplast genome sequence of clusterbean (Cyamopsis tetragonoloba L.): Genome structure and comparative analysis. Genes 2017, 8, 212. [CrossRef]

12. Barrett, C.F.; Freudenstein, J.V.; Li, J.; Mayfield-Jones, D.R.; Perez, L.; Pires, J.C.; Santos, C. Investigating the path of plastid genome degradation in an early-transitional clade of heterotrophic orchids, and implications for heterotrophic angiosperms. Mol. Biol. Evol. 2014, 31, 3095-3112. [CrossRef]

13. Sveinsson, S.; Cronk, Q. Evolutionary origin of highly repetitive plastid genomes within the clover genus (Trifolium). BMC Evol. Biol. 2014, 14, 218-228. [CrossRef] [PubMed]

14. Haberle, R.C.; Fourcade, H.M.; Boore, J.L.; Jansen, R.K. Extensive rearrangements in the chloroplast genome of Trachelium caeruleum are associated with repeats and tRNA genes. J. Mol. Evol. 2008, 66, 350-361. [CrossRef] [PubMed]

15. Rousseau-Gueutin, M.; Huang, X.; Higginson, E.; Ayliffe, M.; Day, A.; Timmis, J.N. Potential functional replacement of the plastidic acetyl-CoA carboxylase subunit $(a c c D)$ gene by recent transfers to the nucleus in some angiosperm lineages. Plant Physiol. 2013, 161, 1918-1929. [CrossRef] [PubMed]

16. Kode, V.; Mudd, E.A.; Lamtham, S.; Day, A. The tobacco plastid accD gene is essential and is required for leaf development. Plant J. Cell Mol. Biol. 2005, 44, 237-244. [CrossRef] [PubMed]

17. Adams, K.L.; Chuan, O.H.; Palmer, J.D. Mitochondrial gene transfer in pieces: Fission of the ribosomal protein gene $r p l 2$ and partial or complete gene transfer to the nucleus. Mol. Biol. Evol. 2001, 18, 2289-2297. [CrossRef]

18. Kim, H.T.; Kim, J.S.; Moore, M.J.; Neubig, K.M.; Williams, N.H.; Whitten, W.M.; Kim, J.H. Seven new complete plastome sequences reveal rampant independent loss of the $n d h$ gene family across orchids and associated instability of the inverted repeat/small single-copy region boundaries. PLoS ONE 2015, 10, e0142215. [CrossRef]

19. Xi, L.; Zhang, T.C.; Qiao, Q.; Ren, Z.M.; Zhao, J.; Yonezawa, T.; Hasegawa, M.; Crabbe, M.J.; Li, J.Q.; Zhong, Y. Complete chloroplast genome sequence of holoparasite Cistanche deserticola (Orobanchaceae) reveals gene loss and horizontal gene transfer from its host Haloxylon ammodendron (Chenopodiaceae). PLoS ONE 2013,8, e58747.

20. Cai, Z.Q.; Guisinger, M.; Kim, H.G.; Ruck, E.; Blazier, J.C.; McMurtry, V.; Kuehl, J.V.; Boore, J.; Jansen, R.K. Extensive reorganization of the plastid genome of Trifolium subterraneum (Fabaceae) is associated with numerous repeated sequences and novel DNA insertions. J. Mol. Evol. 2008, 67, 696-704. [CrossRef]

21. Yang, Y.; Tao, Z.; Dong, D.; Jia, Y.; Li, F.; Zhao, G.F. Comparative analysis of the complete chloroplast Genomes of five Quercus species. Front. Plant Sci. 2016, 7, 944-959. [CrossRef] [PubMed]

22. Sajjad, A.; Muhammad, W.; Abdul, L.K.; Muhammad, A.K.; Sang-Mo, K.; Qari, M.I.; Raheem, S.; Saqib, B.; Byung-Wook, Y.; In-Jung, L. The complete chloroplast genome of wild rice (Oryza minuta) and its comparison to related species. Front. Plant Sci. 2017, 8, 289-304.

23. Millen, R.S.; Olmstead, R.G.; Adams, K.L. Many parallel losses of infA from chloroplast DNA during Angiosperm evolution with multiple independent transfers to the nucleus. Cochrane Database Syst. Rev. 2001, 13, 645-658. 
24. Jansen, R.K.; Wojciechowski, M.F.; Sanniyasi, E.; Lee, S.B.; Daniell, H. Complete plastid genome sequence of the chickpea (Cicer arietinum) and the phylogenetic distribution of rps12 and clpP intron losses among legumes (Leguminosae). Mol. Phylogenet. Evol. 2008, 48, 1204-1217. [CrossRef]

25. Tao, X.L.; Ma, L.C.; Zhang, Z.S.; Liu, W.X.; Liu, Z.P. Characterization of the complete chloroplast genome of alfalfa (Medicago sativa) (Leguminosae). Gene Rep. 2017, 6, 67-73. [CrossRef]

26. Shi, C.; Wang, S.; Xia, E.H.; Jiang, J.J.; Zeng, F.C.; Gao, L.Z. Full transcription of the chloroplast genome in photosynthetic eukaryotes. Sci. Rep. 2016, 6, 30135. [CrossRef]

27. Pasquale, L.C.; Domenico, D.P.; Donatella, D.; Giovanni, G.V.; Gabriella, S. Complete chloroplast genome of the multifunctional crop globe artichoke and comparison with other Asteraceae. PLoS ONE 2015, 10, e120589.

28. Xiao, L. Intra-genomic polymorphism in the internal transcribed spacer (ITS) regions of Cycas revoluta: Evidence of incomplete concerted evolution. Biodivers. Sci. 2009, 17, 476-481.

29. Goremykin, V.V.; Hirsch-Ernst, K.I.; Wölfl, S.; Hellwig, F.H. Analysis of the Amborella trichopoda chloroplast genome sequence suggests that Amborella is not a basal Angiosperm. Mol. Biol. Evol. 2003, 9, 1499-1505. [CrossRef]

30. Wright, F. The 'effective number of codons' used in a gene. Gene 1990, 87, 23-29. [CrossRef]

31. Li, Y.F.; Sylvester, S.P.; Li, M.; Zhang, C.; Li, X.; Duan, Y.F.; Wang, X.R. The complete plastid genome of agnolia zenii and genetic comparison to Magnoliaceae species. Molecules 2019, 24, 261. [CrossRef]

32. Talat, F.; Wang, K. Comparative bioinformatics analysis of the chloroplast genomes of a wild diploid Gossypium and two cultivated allotetraploid species. Iran. J. Biotechnol. 2015, 13, 47-56. [CrossRef] [PubMed]

33. Wheeler, G.L.; Dorman, H.E.; Buchanan, A.; Challagundla, L.; Wallace, L.E. A review of the prevalence, utility, and caveats of using chloroplast simple sequence repeats for studies of plant biology. Appl. Plant Sci. 2014, 2, 1400059. [CrossRef] [PubMed]

34. Saski, C.; Lee, S.; Daniell, H.; Wood, T.C.; Tomkins, J.; Kim, H.; Jansen, R.K. Complete chloroplast genome sequence of Glycine max and comparative analyses with other legume genomes. Plant Mol. Biol. 2005, 59, 309-322. [CrossRef] [PubMed]

35. Morgante, M.; Pfeiffer, A.; Costacurta, A.; Olivieri, A.M.; Rafalski, J.A. Polymorphic Simple Sequence Repeats in Nuclear and Chloroplast Genomes: Applications to the Population Genetics of Trees; Springer: Dordrecht, the Netherlands, 1996.

36. Hu, Y.; Woeste, K.E.; Zhao, P. Completion of the chloroplast genomes of five Chinese Juglans and their contribution to chloroplast phylogeny. Front. Plant Sci. 2017, 7, 1939-1955. [CrossRef]

37. Ebert, D.; Peakall, R.O. Chloroplast simple sequence repeats (cpSSRs): Technical resources and recommendations for expanding cPSSR discovery and applications to a wide array of plant species. Mol. Ecol. Resour. 2009, 9, 673-690. [CrossRef]

38. Tachida, H. Evolution of repeated sequences in non-coding regions of the genome. Jpn. J. Genet. 1993, 68, 549-565. [CrossRef]

39. Wei, Y.L.; Wen, Z.F.; Liu, F.; Zhang, J.W.; Huang, W.G.; Lan, Y.P.; Cheng, L.L.; Cao, Q.C.; Hu, G.G.; Yun, C. Bioinformatics analysis of ycf1 gene in Corylus. J. Shanxi Agric. Sci. 2018, 46, 1244-1247.

40. Raes, J.; Van, D.P.Y. Functional divergence of proteins through frameshift mutations. Trends Genet. 2005, 21, 428-431. [CrossRef]

41. Bobrova, V.K.; Troitsky, A.V.; Ponomarev, A.G.; Antonov, A.S. Low-molecular-weight rRNAs sequences and plant phylogeny reconstruction: Nucleotide sequences of chloroplast $4.5 \mathrm{~S}$ rRNAs from Acorus calamus (Araceae) and Ligularia calthifolia (Asteraceae). Plant Syst. Evol. 1987, 156, 13-27. [CrossRef]

42. Masood, M.S.; Nishikawa, T.; Fukuoka, S.; Njenga, P.K.; Tsudzuki, T.; Kadowaki, K. The complete nucleotide sequence of wild rice (Oryza nivara) chloroplast genome: First genome wide comparative sequence analysis of wild and cultivated rice. Gene 2004, 340, 133-139. [CrossRef]

43. Su, H.J.; Hogenhout, S.A.; Al-Sadi, A.M.; Kuo, C.H. Complete chloroplast genome sequence of Omani lime (Citrus aurantiifolia) and comparative analysis within the Rosids. PLoS ONE 2014, 11, e113049. [CrossRef]

44. Song, Y.; Dong, W.P.; Liu, B.; Xu, C.; Yao, X.; Gao, J.; Richard, T.C. Comparative analysis of complete chloroplast genome sequences of two tropical trees Machilus yunnanensis and Machilus balansae in the family Lauraceae. Front. Plant Sci. 2015, 6, 662-670. [CrossRef] 
45. Doorduin, L.; Gravendeel, B.; Lammers, Y.; Ariyurek, Y.; Chin-A-Woeng, T.; Vrieling, K. The complete chloroplast genome of 17 individuals of pest species Jacobaea vulgaris: SNPs, microsatellites and barcoding markers for population and phylogenetic studies. DNA Res. 2011, 18, 93-105. [CrossRef]

46. Nei, M.; Kumar, S. Molecular Evolution and Phylogenetics; Oxford University Press: Oxford, UK, 2000.

47. Yi, L. Comparing and analyzing on models of calculation and statistical testing of nonsynonymous substitution rate and synonymous substitution rate during gene evolution. J. Qujing Norm. Univ. 2006, 25, 1-6.

48. Perry, A.S.; Wolfe, K.H. Nucleotide substitution rates in legume chloroplast DNA depend on the presence of the inverted repeat. J. Mol. Evol. 2002, 55, 501-508. [CrossRef]

49. Bittner-Eddy, P.D.; Crute, I.R.; Holub, E.B.; Beynon, J.L. RPP13 is a simple locus in Arabidopsis thaliana for alleles that specify downy mildew resistance to different avirulence determinants in Peronospora parasitica. Plant J. 2010, 21, 177-188. [CrossRef]

50. Dong, W.L.; Wang, R.N.; Zhang, N.Y.; Fan, W.B.; Fang, M.F.; Li, Z.H. Molecular evolution of chloroplast genomes of Orchid species: Insights into phylogenetic relationship and adaptive evolution. Int. J. Mol. Sci. 2018, 19, 716. [CrossRef]

51. Zhang, L. Collection and Annotation of Suinong14 Full-Length Transcripts and Gene Diversity Analysis of Glyma13g21630; Chinese Academy of Agricultural Science: Beijing, China, 2011.

52. Malaviya, D.R.; Roy, A.K.; Kaushal, P.; Kumar, B.; Tiwari, A. Genetic similarity among Trifolium species based on isozyme banding pattern. Plant Syst. Evol. 2008, 276, 125-136. [CrossRef]

53. Langmead, B.; Salzberg, S.L. Fast gapped-read alignment with Bowtie 2. Nat. Methods 2012, 9, 357-359. [CrossRef]

54. Bankevich, A.; Nurk, S.; Antipov, D.; Gurevich, A.A.; Dvorkin, M.; Kulikov, A.S.; Pyshkin, A.V. SPAdes: A new genome assembly algorithm and its applications to single-cell sequencing. J. Comput. Biol. 2012, 19, 455-477. [CrossRef]

55. Acemel, R.D.; Tena, J.J.; Irastorza-Azcarate, I.; Marlétaz, F.; Gómez-Marín, C.; Calle-Mustienes, E.; Mangenot, S. A single three-dimensional chromatin compartment in amphioxus indicates a stepwise evolution of vertebrate Hox bimodal regulation. Nat. Genet. 2016, 48, 336-341. [CrossRef]

56. Nadalin, F.; Vezzi, F.; Policriti, A. GapFiller: A de novo assembly approach to fill the gap within paired reads. BMC Bioinform. 2012, 13, S8. [CrossRef]

57. Laslett, D.; Canback, B. ARAGORN, a program to detect tRNA genes and tmRNA genes in nucleotide sequences. Nucleic Acids Res. 2004, 32, 11-16. [CrossRef]

58. Lowe, T.M.; Chan, P.P. tRNAscan-SE On-line: Integrating search and context for analysis of transfer RNA genes. Nucleic Acids Res. 2016, 44, W54-W57. [CrossRef]

59. Kearse, M.; Moir, R.; Wilson, A.; Stones-Havas, S.; Cheung, M.; Sturrock, S.; Thierer, T. Geneious Basic: An integrated and extendable desktop software platform for the organization and analysis of sequence data. Bioinformatics 2012, 28, 1647-1649. [CrossRef]

60. Wyman, S.K.; Jansen, R.K.; Boore, J.L. Automatic annotation of organellar genomes with DOGMA. Bioinformatics 2004, 20, 3252-3255. [CrossRef]

61. Kumar, S.; Nei, M.; Dudley, J.; Tamura, K. MEGA: A biologist-centric software for evolutionary analysis of DNA and protein sequences. Brief. Bioinform. 2008, 9, 299-306. [CrossRef]

62. Darling, A.C.E.; Mau, B.; Blattner, F.R.; Perna, N.T. Mauve: Multiple alignment of conserved genomic sequence with rearrangements. Genome Res. 2004, 14, 1394-1403. [CrossRef]

63. Zhang, Z.; Li, J.; Zhao, X.Q.; Wang, J.; Wong, G.K.S.; Yu, J. KaKs_Calculator: Calculating Ka and Ks through model selection and model averaging. Genom. Proteom. Bioinform. 2006, 4, 259-263. [CrossRef]

64. Danecek, P.; Auton, A.; Abecasis, G.; Albers, C.A.; Banks, E.; Depristo, M.A.; McVean, G. The variant call format and VCFtools. Bioinformatics 2011, 27, 2156-2158. [CrossRef]

65. Katoh, K.; Standley, D.M. MAFFT multiple sequence alignment software version 7: Improvements in performance and usability. Mol. Biol. Evol. 2013, 30, 772-780. [CrossRef]

66. Drummond, A.J.; Suchard, M.A.; Xie, D.; Rambaut, A. Bayesian phylogenetics with BEAUti and the BEAST 1.7. Mol. Biol. Evol. 2012, 29, 1969-1973. [CrossRef]

(C) 2020 by the authors. Licensee MDPI, Basel, Switzerland. This article is an open access article distributed under the terms and conditions of the Creative Commons Attribution (CC BY) license (http://creativecommons.org/licenses/by/4.0/). 